\title{
Compressive Stress Relaxation Properties of Polyester and Cupra Fiber Assemblies
}

\author{
NAKAJIMA Chie ${ }^{\mathrm{a}}$, Yoneda Morihiro ${ }^{\mathrm{b}, *}$, ITOH Yuu ${ }^{\mathrm{b}}$ \\ ${ }^{a}$ Graduate School of Human Culture, Nara Women's University, Kitauoya-Nishimachi, Nara 630-8506 Japan \\ ${ }^{\mathrm{b}}$ Faculty of Human Life and Environment, Nara Women's University, Kitauoya-Nishimachi, Nara 630-8506 Japan
}

Received 28 July 2009; accepted for publication 11 October 2009

\begin{abstract}
In this paper, the compressive stress relaxation properties of cylindrical fiber assembly made of polyester fibers with heteromorphic section, polyester fibers with round section and cupro-ammonium rayon fibers are investigated experimentally with regard to sleeping comfort. The results are obtained as follows.

(1) Experimental curve of $S_{Y}$, residual stress ratio is expressed by following empirical equation.

$$
\mathrm{S}_{\mathrm{Y}}=\sigma / \sigma_{0}=\mathrm{K}\left(\mathrm{a}_{0}-\ln t\right)
$$

where, $\sigma$ : stress at time $t(\mathrm{~Pa}), \sigma_{0}$ : initial stress $(\mathrm{Pa}), t$ : time(s), $\mathrm{K}\left(\right.$ n.d.) and $\mathrm{a}_{0}($ n.d.) : constants determined by fiber type and measurement condition. The results indicate that compressive stress relaxation phenomena of synthetic and regenerated fiber assembly show non-linear visco-elastic behaviour.

(2) Residual stress ratio at a certain time $t$ of polyester fibers with w-shaped heteromorphic section and with round section has minimum value at 0.0179 in volume fraction, and that of cupra fiber is minimized at 0.0208 in volume fraction. The results indicate that the above conditions must be avoided in order to prevent large reduction of fiber volume in terms of preservation.

(3) Compression stress relaxation phenomena of cupra staple fiber assembly is expressed by following equation derived from non-linear two element visco-elastic model.

$$
\mathrm{S}_{\mathrm{Y}}=\sigma / \sigma_{0}=\mathrm{K} \ln \left[\operatorname{coth}\left\{1 / 2\left(2 \mathrm{e}^{-\mathrm{a} 0} t+\mathrm{B}\right)\right\}\right]
$$

where, $\mathrm{K}, \mathrm{a}_{0}$ and $\mathrm{B}$ are constants determined by experiment. In contrast, compression stress relaxation phenomena of polyester staple fiber assemblies with heteromorphic section and round section is not expressed by this equation.
\end{abstract}

Key Words: Fiber assembly, Compression, Stress relaxation, Visco-elastic model, Cupra fiber, Polyester fiber

\section{ポリエステル繊維・キュプラ繊維集合体の圧縮応力緩和特性}

\author{
中島千恵 ${ }^{a}$, 米田守宏 ${ }^{b, *}$, 伊藤 優 $^{\mathrm{b}}$ \\ a 奈良女子大学大学院人間文化研究科, ${ }^{b}$ 奈良女子大学生活環境学部
}

\section{1. 緒 言}

敷きふとんの寝心地にかかわる要求性能として, 保温性抒 よび吸放湿性などの快適な寝床内環境を保つための熱・水分 移動特性と, 良い寝姿勢を保ち, 寝返りがしやすいといった 身体支持性にかかわる力学的特性が挙げられる. 最初に消費 者が敷きふとんを購入しようとする際, 手触りや圧縮性, 弾 力性などが購入動機の直接要因であると考えられる。 そして
敷きふとんの寝心地にかかわる実用性能拧よび取扱い性など の消費性能に押いては，長期間の使用に耐久性があることが 求められる. 良い寝姿勢を保つために背骨をまっすぐに保ち, 身体を支える安定性に優れた敷きふとんは, 繰り返し圧縮時 の回復性に優れている. そして長時間の加圧下において応力 低下が小さく，へたりが少ない。しかも長年使っている間に 硬く締まって, 一般的に言われるセンべイ布団状態になるこ となく, 弾力性および圧縮回復性が初期の性能を保持できる

* 連絡先： $\overline{\mathrm{T}}$ 630-8506 奈良市北魚屋西町 奈良女子大学 生活環境学部 米田 守宏

E-mail: yoneda@cc.nara-wu.ac.jp, Tel/Fax: +81-742-20-3463 


\section{ことが必要と考えられる.}

第一報では，ポリエステル繊維・キュプラ繊維集合体の繰 り返し圧縮・回復挙動について報告した [1]. 寝装用中わた 部材を構成する繊維として現在流通している合成繊維や再生 繊維の中から, 素材と繊維断面形状の違いによる短繊維集合 体の特徵を明確にするために, 繊度と繊維長をほぼ等しくし, 素材と断面形状の異なる短繊維として, 異型断面ポリエステ ル短繊維, 丸断面ポリエステル短繊維およびキュプラ短繊維 の3 種を選別し, 試料の作成方法および圧縮試験条件を見極 めた。そして, これら 3 種の円柱状繊維集合体について, 繰 り返し圧縮・回復過程における圧縮変形および圧縮・回復工 ネルギー変化の挙動について検討した結果, 体積率 0.0125 , 最大圧縮応力 $1176 \mathrm{~Pa}$ の条件下に打ける, 繰り返し圧縮 6 回 目の圧縮・回復特性に各試料の特徵が現れることを明らかに した.この 6 回目の圧縮・回復曲線の形状について, リニア ライジング法を適用し解析した結果, 圧縮応力と圧縮変形量 の関係は両対数グラフ上において直線関係を示し, $\mathrm{Pc}=\mathrm{AT}^{\mathrm{n}}$ の表示式を導いた，寝心地の良さを左右すると考えられる圧 縮の回復過程における各試料の $\mathrm{n}$ 值を求め, 本研究の実験条 件下では, 異型断面ポリエステルと丸断面ポリエステルは 2 より大きい值を示し, キュプラは 2 より小さい值を示すこと 等を報告している.

圧縮・回復特性の機構をより梁く理解するためには, 繊維 集合体の圧縮にかかわる粘弾性特性を知ることが基礎的に必 要である.これまで, 繊維集合体の圧縮に関連する研究は数 多いが [2-9], 圧縮にかかわる粘弾性的性質, たとえば応力緩 和やクリープ現象などについての研究は少ない. わずかに野 飼, 鳴海による綿繊維塊の圧縮応力緩和に関する実験 [10] お よび綿繊維塊の圧縮クリープ挙動についての研究 [11], 松尾, Lei Lu による融着繊維塊の圧縮挙動 [12] が挙げられるにすぎ ない.

さらに敷きふとんの寝心地にかかわる実用性能の観点か ら, 身体支持の安定感を得るためには, 臥床時の弾性反発力 が低下せず，弾力保持性に優れ，へたりにくいことが重要で
ある。この特性は, 繊維集合体の圧縮応力緩和特性と関連が 深い.

そこで本研究では圧縮応力緩和特性を取り上げ，寝装用中 わた部材を構成する合成繊維や再生繊維の中から，素材と繊 維断面形状の違いによる短繊維集合体の特徴を明確にするた めに, 繊度と繊維長をほほ等しくし，素材と断面形状の異な る短繊維として, 異型断面ポリエステル短繊維, 丸断面ポリ エステル短繊維およびキュプラ短繊維の 3 種を選別し, これ ら 3 種の円柱状繊維集合体についてその挙動を実験的に検討 する.

\section{2. 実 験}

\section{1 試料}

実験に使用した短繊維材料は異型断面ポリエステル短緎 維, 丸断面ポリエステル短繊維およびキュプラ短繊維の 3 種 の原綿を開繊し，カーディングしたウェブを用い，標準状態 $20 \pm 2^{\circ} \mathrm{C}, 65 \pm 2 \% \mathrm{RH}$ 中の環境条件中で 24 時間以上調湿し た後に実験に供した。これら試料の記号を Table 1 に，その 性状を Table 2 に示す。緎度, 繊維長, けん縮数, けん縮率, 見掛けヤング率の測定は，JIS L 1015 に準じて実測した。 曲げ剛性 B $\left(\mathrm{gf} \cdot \mathrm{cm}^{2}\right)$ の算出は以下の方法で行った． 短繊維 断面写真をデジタイズしてコンピューターに取り込み, 画 像処理ソフト (Win ROOF) を用いて, 断面 2 次モーメント $\mathrm{I}\left(\mu \mathrm{m}^{4}\right)$ を求める。曲げ剛性 B $\left(\mathrm{gf} \cdot \mathrm{cm}^{2}\right)$ は, 先に求めた見掛 けヤング率 $\mathrm{E}\left(\mathrm{kgf} / \mathrm{mm}^{2}\right)$ と断面 2 次モーメント $\mathrm{I}\left(\mu \mathrm{m}^{4}\right)$ の積, すなわち， B = E × I で表せる. 試料の断面形状を Fig. 1 に 示す.

圧縮応力緩和試験における主要な測定条件として，繊維体 積率があるがこれは以下のように見積もった。市販敷ふとん の標準寸法を縦 $200 \mathrm{~cm} \times$ 横 $100 \mathrm{~cm} \times$ 厚み $8 \mathrm{~cm}$, 中わた重 量を $4 \mathrm{~kg}$ として, $0.025 \mathrm{~g} / \mathrm{cm}^{3}$ を標準密度とした。ここで素材 毎の繊維体積率をほぼ等しくし，繊維の分布が一様になるよ

Table 1 Sample code.

\begin{tabular}{|c|l|}
\hline Sample code & \multicolumn{1}{c|}{ Detail of sample } \\
\hline WP & Polyester staple fiber with w-shaped heteromorphic section \\
\hline RP & Polyester staple fiber with round section \\
\hline $\mathrm{Cu}$ & Cupra-ammonium (Cupra) staple fiber \\
\hline
\end{tabular}

Table 2 Details of fiber samples for wadding use.

\begin{tabular}{|c|c|c|c|c|c|c|c|c|}
\hline Sample code & $\begin{array}{c}\text { Fineness } \\
\text { (dtex) }\end{array}$ & $\begin{array}{c}\text { Fiber length } \\
(\mathrm{mm})\end{array}$ & $\begin{array}{c}\text { Specific gravity } \\
(-)\end{array}$ & $\begin{array}{l}\text { Number of crimp } \\
\text { (unit/25mm) }\end{array}$ & $\begin{array}{l}\text { Percentage of crimp } \\
(\%)\end{array}$ & $\begin{array}{c}\text { Apparent young's modulus } \\
\left(\mathrm{kgf} / \mathrm{mm}^{2}\right) \\
\end{array}$ & $\begin{array}{c}\text { Bending rigidity } \mathrm{B}_{\mathrm{X}}{ }^{* 1} \\
\left(\mathrm{gf} \cdot \mathrm{cm}^{2}\right)\end{array}$ & $\begin{array}{c}\text { Bending rigidity } \mathrm{B}_{\mathrm{Y}}{ }^{* 2} \\
\left(\mathrm{gf} \cdot \mathrm{cm}^{2}\right)\end{array}$ \\
\hline WP & 1.4 & 34.85 & 1.38 & 15.47 & 10.84 & 347.3 & $1.61 \times 10^{-5}$ & $1.98 \times 10^{-6}$ \\
\hline $\mathrm{RP}$ & 1.3 & 35.68 & 1.38 & 13.87 & 12.07 & 459.8 & $6.34 \times 10^{-6}$ & $5.87 \times 10^{-6}$ \\
\hline $\mathrm{Cu}$ & 1.4 & 34.24 & 1.50 & 9.44 & 8.94 & 770.8 & $8.04 \times 10^{-6}$ & $7.75 \times 10^{-6}$ \\
\hline
\end{tabular}

$* 1 \mathrm{~B}_{\mathrm{X}}$ : bending rigidity along the $\mathrm{X}$-axis direction.

$* 2 \mathrm{~B}_{\mathrm{Y}}$ : bending rigidity along the $\mathrm{Y}$-axis direction. 
うに, 素材によって必要な試料重量をあらかじめ設定するた めに, 目標とする体積率を定義した. この目標とする体積率 は繊維集合体の見掛けの体積に対する繊維の実体積の割合で あり, 以下のようにして求めた。本研究においては円柱状試 料を使用したため, 試料重量を $\mathrm{W}(\mathrm{g})$, 繊維の比重を $\rho$, 直 径を $\mathrm{d}(\mathrm{cm})$, 高さを $\mathrm{h}(\mathrm{cm})$ とすると, 体積率 $\lambda$ は,

$$
\lambda=(\mathrm{W} / \rho) /(1 / 4) \pi \mathrm{d}^{2} \mathrm{~h} \doteqdot 1.27 \times \mathrm{W} / \mathrm{\rho d}^{2} \mathrm{~h}
$$

で表される. この一定量の短繊維材料を, 直径 $54 \mathrm{~mm}$, 高さ $100 \mathrm{~mm}$ の円柱セルの中にできるだけ均一になるように，ガラ ス棒とピンセットを使用して円柱セル内に充填した後, その 上に直径 $50 \mathrm{~mm}$, 厚み $4 \mathrm{~mm}$, 重さ $10 \mathrm{~g}$ のプラスチック製円板 を静置し, 円柱状の短繊維集合体を実験試料とした。この方 法では, 圧縮作用による試料の横ふくらみや短繊維の飛散が なく試料作製が容易である. ただし, 円柱セルの壁面と繊維 との摩擦の影響が若干懸念されるが, 本研究では摩擦要因を できるだけ小さくするよう表面形状に凹凸が少ないアクリル 樹脂製円柱セルを用いた。 なお, 本研究では体積率の小さい 繊維集合体を対象としているため, 硬わたは対象外とした.
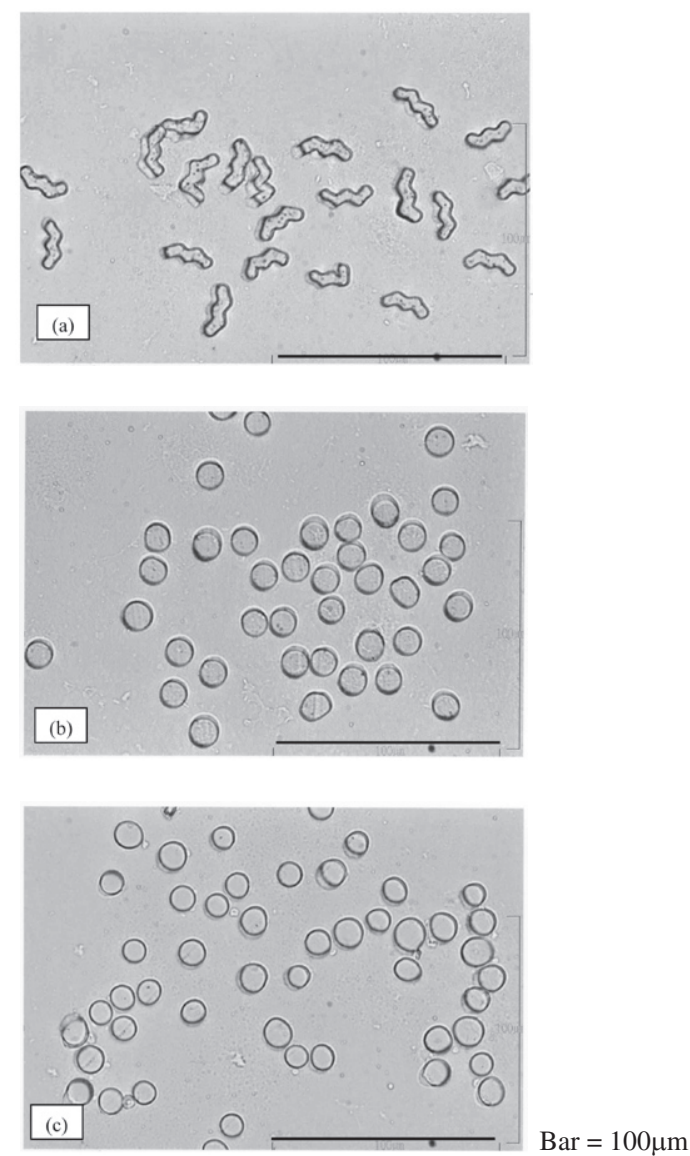

Fig.1 A cross-sectional view of fiber by SEM.

(a) polyester staple fiber with w-shaped super-flat heteromorphic section.

(b) polyester staple fiber with round section.

(c) cupra-ammonium (cupra) staple fiber.

\section{2 実験装置および実験方法}

実験装置は第 1 報で使用したハンデイ圧縮試験機（カトー テック(株)製 KES-G5）を用いた．実験試料の高さが $10 \mathrm{~cm} に$ なるように面積 $20 \mathrm{~cm}^{2}$ の円形の加圧板を調整し, その時点に おける記録計の目盛を 0 に合わせる，すなわち，高さ $10 \mathrm{~cm}$ の状態を負荷 0 と見なす. 次に加圧板を $5 \mathrm{~mm} / \mathrm{sec}$ の速度で 下降させ, 加圧板が所定の変位量 $(1,2,3,4,5 \mathrm{~cm})$ になっ たとき, 加圧板を停止させ，その瞬間を時刻 $0 \mathrm{sec}$ とする. その後力計に接続した加圧板を停止（変位量が一定に固定さ

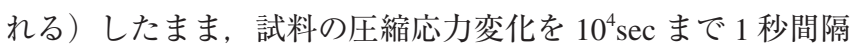
で経時的に測定する. データの解析方法は, 圧縮応力の出力 電圧をデータロガーに取り达み, パソコンにてデータ処理を 行った. なお目標とする体積率は第 1 報で報告したように, 体積率 0.0125 , 最大圧縮応力 $1176 \mathrm{~Pa}$ の条件下において, 繰 り返し圧縮 6 回目の圧縮・回復曲線に各試料の特徴が現れる という結果を考慮して, 体積率 0.0125 に設定した.

\section{3. 結果および考察}

上述の実験方法にしたがって 3 試料の応力緩和を, 変位 量を 5 段階に変えて測定した。得られた結果の例を Fig. 2 〜 Fig. 3 に示す. Fig. 2 は加圧板の変位量が $5 \mathrm{~cm}, \quad$ Fig. 3 は $2 \mathrm{~cm}$ の場合で，いずれにおいても縦軸は応力残留率 $S \gamma$ を普通目 盛で, 横軸は時間 $t(\mathrm{~s})$ を対数目盛で示している.

ここで応力残留率は次式で定義される.

$$
\begin{aligned}
& \mathrm{S} \gamma=\sigma / \sigma_{0} \\
& \sigma \quad: \quad \text { 任意時間における応力 }(\mathrm{Pa}) \\
& \sigma_{0}: \text { 初期応力 (時間 } t=0 \text { における応力) }(\mathrm{Pa})
\end{aligned}
$$

上述の測定結果より明らかなように, 応力残留率曲線は約 $10^{2} \mathrm{sec}$ 以後では片対数グラフ上で直線に近似できる。した がって応力残留率曲線は次式で表すことができる.

$$
\mathrm{S} \gamma=\mathrm{K}\left(\mathrm{a}_{0}-\ln t\right)
$$

ここで $t$ は時間 $(\mathrm{s}), \mathrm{K}$ （無次元）および $\mathrm{a}_{0}$ （無次元）は試料 種別および測定条件によって決まる定数である. 測定結果に 対して最小 2 乗法を適用し, 各試料について上式の各定数を 求めた。 結果を Table 3 に示す.

Fig. 2, 3 からわかるようにキュプラ短繊維の緩和速度は 他のポリエステル短繊維よりも明らかに速い.このことは, Table 3 の各変位条件における K 值の大小に現れている.すな わち, いかなる変位条件においてもキュプラの K 值は異型断 面ポリエステルおよび丸断面ポリエステルの約 2 倍以上であ る. また，異型断面ポリエステルと丸断面ポリエステルの $\mathrm{K}$ 值を比べると, 異型断面ポリエステルの K 值の方が丸断面ポ リエステルの $\mathrm{K}$ 值に比べて小さい，K 值が小さいほど圧縮に よる応力緩和速度が緩やかである.すなわち弾力保持性が高 


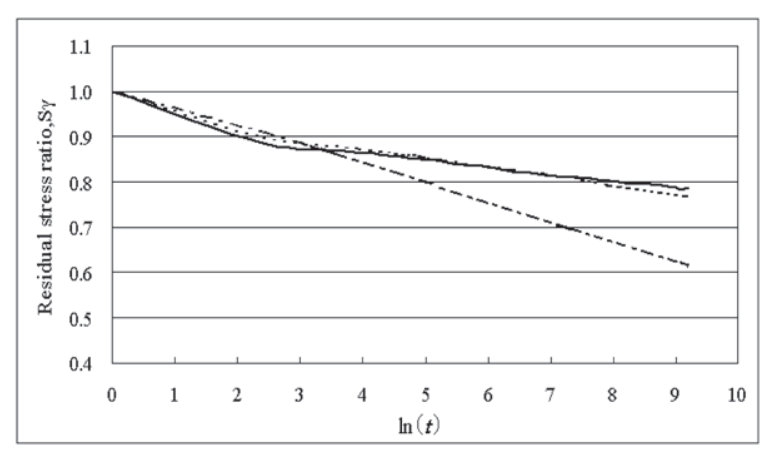

Fig.2 The compression stress relaxation curve when compression displacement is $5 \mathrm{~cm}$.

Sample is compressed from 0.0125 to 0.025 in volume fraction. Straight line : Polyester staple fiber with w-shaped heteromorphic section.

Dotted line : Polyester staple fiber with round section. Dots and dashes line : Cupra staple fiber.

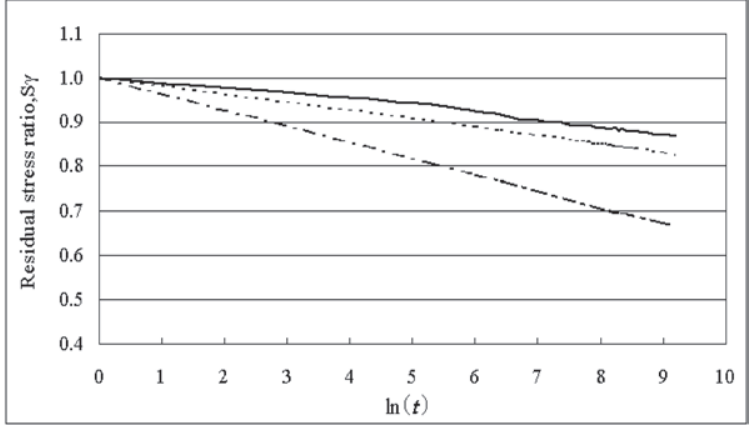

Fig.3 The compression stress relaxation curve when compression displacement is $2 \mathrm{~cm}$.

Sample is compressed from 0.0125 to 0.0156 in volume fraction. Straight line : Polyester staple fiber with $\mathrm{w}$-shaped heteromorphic section.

Dotted line : Polyester staple fiber with round section. Dots and dashes line : Cupra staple fiber.

Table 3 The results of initial stress, $\sigma_{0}$ and the calculated values of coefficients, $K$ and $a_{0}$ based on experimental curves.

\begin{tabular}{|c|c|c|c|c|c|c|c|c|c|c|c|c|c|c|c|c|}
\hline $\begin{array}{c}\text { Compression } \\
\text { displacement }\end{array}$ & \multicolumn{3}{|c|}{$1 \mathrm{~cm}$} & \multicolumn{3}{c|}{$2 \mathrm{~cm}$} & \multicolumn{3}{c|}{$3 \mathrm{~cm}$} & \multicolumn{3}{c|}{$5 \mathrm{~cm}$} & \multicolumn{3}{c|}{0.0208} & \multicolumn{3}{c|}{0.025} \\
\hline Volume fraction & \multicolumn{3}{|c|}{0.0139} & \multicolumn{3}{c|}{0.0156} & \multicolumn{3}{c|}{0.0179} & \multicolumn{2}{c|}{$\mathrm{a}^{2}$} \\
\hline Sample code & $\sigma_{0}(\mathrm{~Pa})$ & $\mathrm{K}$ & $\mathrm{a}_{0}$ & $\sigma_{0}(\mathrm{~Pa})$ & $\mathrm{K}$ & $\mathrm{a}_{0}$ & $\sigma_{0}(\mathrm{~Pa})$ & $\mathrm{K}$ & $\mathrm{a}_{0}$ & $\sigma_{0}(\mathrm{~Pa})$ & $\mathrm{K}$ & $\mathrm{a}_{0}$ & $\sigma_{0}(\mathrm{~Pa})$ & $\mathrm{K}$ & $\mathrm{a}_{0}$ \\
\hline $\mathrm{WP}$ & 336.14 & 0.0175 & 59.16 & 628.18 & 0.0174 & 59.02 & 796.74 & 0.0110 & 78.02 & 1205.89 & 0.0128 & 68.57 & 1557.22 & 0.0142 & 64.42 \\
\hline $\mathrm{RP}$ & 653.66 & 0.0221 & 47.55 & 1219.12 & 0.0204 & 49.69 & 1483.72 & 0.0195 & 49.13 & 1719.41 & 0.0198 & 48.47 & 2100.14 & 0.0214 & 45.00 \\
\hline $\mathrm{Cu}$ & 605.15 & 0.0412 & 26.09 & 971.67 & 0.0381 & 26.53 & 1149.54 & 0.0402 & 25.58 & 1614.55 & 0.0357 & 24.65 & 1913.45 & 0.0438 & 23.19 \\
\hline
\end{tabular}

く,へたりにくいといえる.これまでの研究においても, 綿 などのセルロース系瀻維はへたりやすいことが報告されてい る $[3,4]$. 敷きふとんの寝心地にかかわる実用性能の観点から $\mathrm{K}$ 值は重要である，K值の大小を左右する物性としては，け ん縮数やけん縮率，見掛けヤング率などの構造パラメータ, および繊維の断面形状の違いによる曲げ剛性や緘維間の滑 り, 絾維そのものの粘弾性的性質などが考えられる.

初期応力と繊維集合体の圧縮状態との関係をグラフで示 すと, Fig. 4 が得られる。ここで縦軸は初期応力 $\sigma_{0}(\mathrm{~Pa})$ を, 横軸は体積率入をとり, 各試料について示している. 初期応 力 $\sigma_{0}(\mathrm{~Pa})$ は試料種別にかかわらず, 体積率の増加と共に大 きくなる，試料間の大小関係については，丸断面ポリエステ ルが最も大きく, 次いで, キュプラ, 異型断面ポリエステル の順で小さくなる. ただし体積率が 0.0139 では, 丸断面ポ リエステルとキュプラに顕著な有意差は見られなかった。

\section{1 応力残留率についての考察}

応力残留率と繊維集合体の圧縮状態との関係を検討するた めに, 加圧板が所定の変位量に到達し, $1000 \mathrm{sec}$ 経過後の応 力残留率を各試料について調べた，縦軸に応力残留率 $\mathrm{S} \gamma$ を,
横軸に体積率入をとると Fig. 5 が得られる. 1000 sec 経過後 の円柱七ル内の試料は, 纎維一本一本が受ける応力はほほ均 一に負荷された状態となり，概ね安定域に入っていると考え られる。

Fig. 5 から明らかなように, 応力残留率は体積率の増加とと もに低下し, 異型断面ポリエステルおよび丸断面ポリエステ ルでは，体積率が 0.0179 付近において極小となる．キュプラ は体積率が 0.0208 付近に打いて極小となる。 さらに体積率が 大きくなると，異型断面ポリエステルとキュプラは， 上述と は逆に応力残留率は上昇する傾向を示すのに対し，丸断面ポ リエステルでは応力残留率の変化はほとんど見られない．

上述のように, 瀻維集合体の応力残留率は固有の条件 (本 研究の測定条件の下では, 異型断面ポリエステルおよび丸断 面ポリエステルは $\lambda=0.0179$ 付近, キュプラは $\lambda=0.0208$ 付近）において極小，すなわち応力緩和が極大になる傾向で あることがわかる。したがって繊維集合体が負荷された状態 で長時間放置されるような使用条件の場合には，体積率はか なり重要な要素になるものと考えられる。 たとえば初めに与 えられた圧縮抵抗，すなわち弾力を保持すべき使用条件の下 では，前述の条件，すなわち異型断面ポリエステルおよび丸 断面ポリエステルでは体積率 0.018 近傍㧍よびキュプラでは 
体積率 0.021 近傍という条件を避けなければならない. 特に 異型断面ポリエステルおよびキュプラについてはこの現象が 顕著であるといえる。

\section{2 応力緩和表示式の検討}

測定された応力緩和曲線に (3) 式を適用して求めた Table 2 の結果を, 縦軸に $\mathrm{K}$ および $\mathrm{a}_{0}$, 横軸に体積率をとってプロッ トしたのが Fig. 6 および Fig. 7 である.

Fig. 6 より明らかなように, K 值は体積率の増加とともに 低下するが，試料によって極小值が異なる，異型断面ポリ エステルおよび丸断面ポリエステルは, 体積率 0.0179 付近 で極小值を持つ下に凸なる曲線を描く。キュプラは体積率 0.0208 付近で極小值を持ち, 体積率 0.0208 付近を越えると 急激に高くなっている． 3.1 で述べたように，K 值からも緩 和が極大となる体積率の存在が示される.

Fig. 7 より $\mathrm{a}_{0}$ は, 異型断面ポリエステルについては体積率 0.0179 付近で極大值を持ち, 3.1 で述べた応力残留率が極小 となる体積率とほぼ一致している。 また $\mathrm{a}_{0}$ の体積率に対す

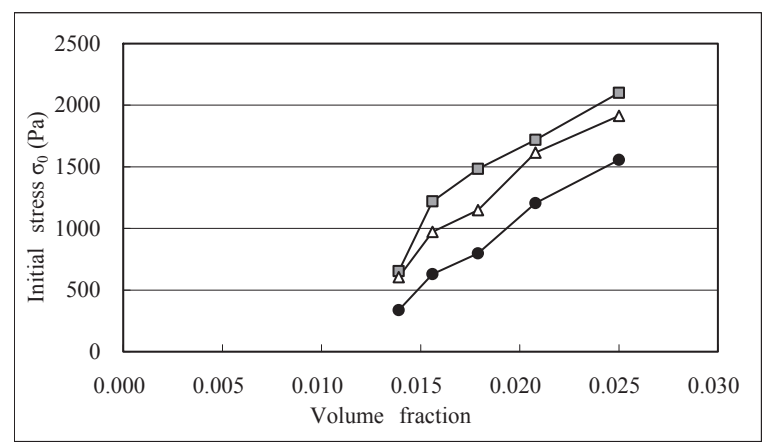

Fig.4 Relationship between initial stress $\sigma_{0}$ and volume fraction.

- : Polyester staple fiber with w-shaped heteromorphic section.

: Polyester staple fiber with round section.

$\triangle$ : Cupra staple fiber.

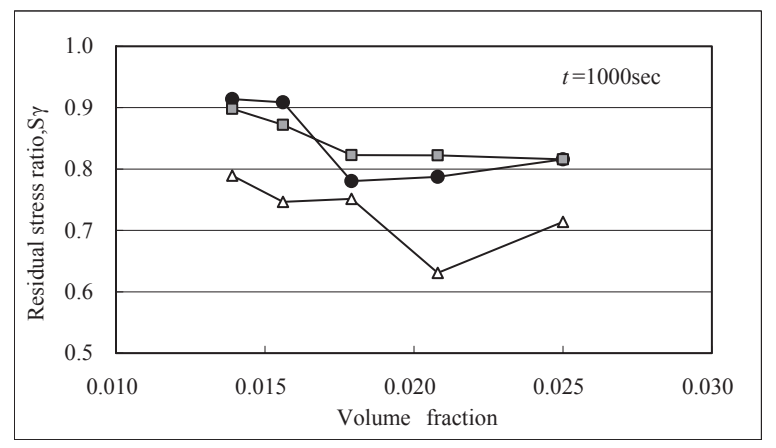

Fig.5 Relationship between residual stress ratio $\mathrm{S}_{\mathrm{Y}}$ and volume fraction at $t=1000 \mathrm{~s}$.

- : Polyester staple fiber with w-shaped heteromorphic section.

: Polyester staple fiber with round section.

$\triangle$ : Cupra staple fiber.
る傾向は $\mathrm{K}$ 值と反対の，極大值を有する上に凸な曲線を描 く，ただし丸断面ポリエステルとキュプラについては体積率 0.0156 付近で最大值を持つが, 体積率の変化による変動は極 めて小さい.

上述のように, 応力緩和の実験式 (3) の定数は, 特定の短 繊維からなる 3 次元繊維集合体の応力緩和の特性をよく表し ており, 実験式 (3) がポリエステル繊維・キュプラ繊維集合 体の応力緩和特性を表す式として適切であることが明らかと なった。

一般に応力緩和を表す力学モデルとして, 単純フォーク トモデル，単純フォークトモデルと弾性ばねが直列に結合 された 3 要素モデルおよび Eyring 非線形 3 要素モデルが考 えられている。そこで本研究においては前述の実験式 (3) を 説明する力学モデルとして, Eyring の反応速度論に基づく非 ニュートンダッシュポットを含む 3 要素モデルを考える。こ のモデルの応力緩和式は,

$$
\sigma=\sigma_{\infty}+(1 / \alpha) \ln [\operatorname{coth}\{1 / 2(\mathrm{~A} t+\mathrm{B})\}]
$$

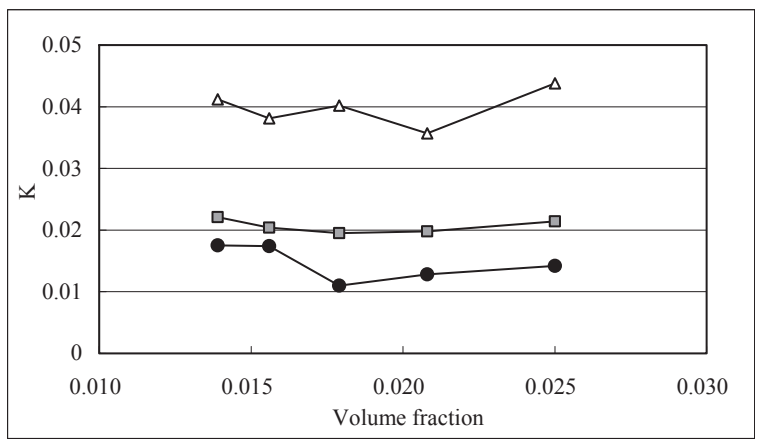

Fig.6 Relationship between $\mathrm{K}$ and volume fraction in equation(3).

- : Polyester staple fiber with w-shaped heteromorphic section. : Polyester staple fiber with round section. $\triangle$ : Cupra staple fiber.

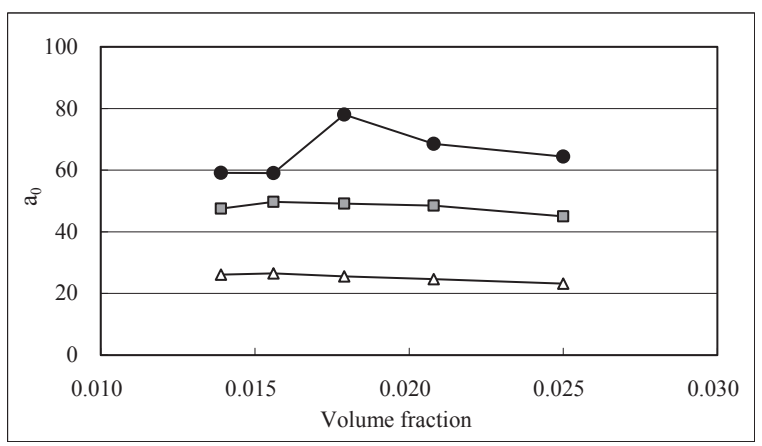

Fig.7 Relationship between $\mathrm{a}_{0}$ and volume fraction in equation(3).

- : Polyester staple fiber with w-shaped heteromorphic section.

: Polyester staple fiber with round section.

$\triangle$ : Cupra staple fiber. 
で表わされる.ここで, $\sigma_{\infty}: t=\propto$ における応力 $(\mathrm{Pa}), \alpha, \mathrm{A}$, $\mathrm{B}$ : 定数. 応力 $\sigma(\mathrm{Pa})$ が $\left(2 / \alpha+\alpha_{\infty}\right)<\sigma<\left(\sigma_{0}-7 / \alpha\right)$ の範囲内で は, (4) 式の近似式として

$$
\sigma=\sigma_{\infty}+(1 / \alpha)\{\ln (2 / \mathrm{A})-\ln t\}
$$

が得られることが示されている [13].

(5) 式を本報の実験式 (3) と比較すると, $\sigma_{\infty}=0$ とすれば時 間 $t(\mathrm{~s})$ に関して全く同じ式表示となる（ただし， $\sigma_{\infty}=0$ とす れば 2 要素モデルとなる)。したがって実験式 (3)で表わさ れる本報の実験データが近似式 (5) に対する厳密式 (4)を満 足するためには，前述の 2 つの近似条件を満たさなければ ならない。これについてはすでに野飼と鳴海ら [10]によっ て，上記条件を満足することが確認されている。すなわち 実験式 (3) は厳密式 (4) の近似式としての条件を満足すると 考えられる。

したがって，ポリエステル繊維・キュプラ繊維集合体の圧 縮応力緩和現象は, Fig. 8 に示すような非ニュートン粘性ダッ シュポットを含む 2 要素モデルで表され, その応力緩和は次 式で表せる.

$$
\mathrm{S} \gamma=\mathrm{K} \ln \left[\operatorname{coth}\left\{1 / 2\left(2 \mathrm{e}^{-\mathrm{a} 0} t+\mathrm{B}\right)\right\}\right]
$$

ここで実験式 (3) 式は上記 (6) 式に近似式として含まれるも のであり，(6) 式は短時間領域においても実験曲線をほほ忠 実に表している箃密な解（以下，㛜密式）であると考えら れる. そこで本研究で得られた応力緩和曲線が(6) 式を満足 するかどうか 3 種の繊維試料について検討した. Table 3 の 数值を代入した一例として, キュプラの体積率 0.0139 の場 合を示すと,

$$
\mathrm{S} \gamma=4.12 \times 10^{-2} \times \ln \operatorname{coth}\left\{(4.68 t+57.5) \times 10^{-12}\right\}
$$

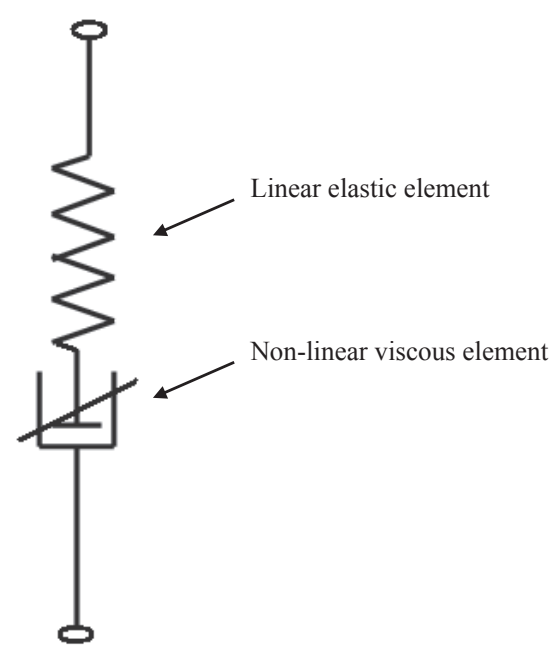

Fig.8 Two element visco-elastic model including non-linear viscous element(dash pot).
となる.ここで B の值は $t=0, \sigma=\sigma_{0}$ を(6) 式に代入する ことによって求めた（7) 式によって計算された各時間にお ける応力残留率 $\mathrm{S} \gamma$ 曲線を, 実験曲線とともに Fig. 9 に示した. ここで縦軸は応力残留率を普通目盛で, 横軸は時間 $t(\mathrm{~s})$ を対 数目盛で示している.

Fig.9 より明らかなように，(6) 式に基づく計算曲線 (7) 式 は短時間領域においても実験曲線とほとんど一致した。この ような計算曲線と実験曲線の良好な一致は，キュプラにおい てはいずれの条件の場合についても同じように見られた。 そ の例を Fig. 10 および Fig. 11 に示す. Fig. 10 は体積率 0.0156 の場合において，(6) 式を用いて計算した結果を実測曲線と ともに示している. Fig. 11 は体積率 0.025 の場合において, (6) 式を用いて計算した結果を実測曲線とともに示している. キュプラ繊維は野飼と鳴海が研究対象として取り上げた綿繊 維と同じくセルロース系繊維であり, 応力緩和の程度が大き いという力学特性における共通点をもつため, (6) 式により その挙動を表すことができるものと考えられる.

一方，異型断面ポリエステルおよび丸断面ポリエステルの 合成繊維では応力緩和挙動が厳密式 (6) で表すことができ なかった。これは実験式 (3)の K 值の大きさが, キュプラ とポリエステルで異なるためである，本研究で用いた実験装 置および測定条件の下では，異型断面ポリエステルの $\mathrm{K}$ 值 は $0.0110 \sim 0.0175$, 丸断面ポリエステルは $0.0195 \sim 0.0221$ の範囲にあるのに対し，キュプラの K 值は $0.0357 〜 0.0438$ の範囲である。すなわち異型断面ポリエステルおよび丸断面 ポリエステルの合成繊維の $\mathrm{K}$ 值はキュプラの $\mathrm{K}$ 值に比べる とかなり小さい.この場合, 他のパラメータ $\mathrm{B}$ は求められ なくなる。ここで測定に供したポリエステル繊維は応力緩和 の速度が小さく，キュプラ繊維とは緩和機構が異なると推測 されるため，(6) 式が適用できないものと考えられる。

以上の結果から, キュプラ繊維集合体の圧縮応力緩和現象 は, 本研究で用いた測定条件の範囲内で, 弾性項と非線形粘 性項（Eyring 粘性項）を直列に接続した非線形 2 要素モデル により記述できる。キュプラ纎維集合体の圧縮応力緩和現象 における緩和は, キュプラ繊維における非線形粘性要素によ るものであり, 測定時間中に構成要素間に多少の滑りが生じ る程度の比較的弱い結合（二次結合）が支配的であるものと 推測される。 そして, その機構は, 野飼らが研究で取り扱っ た綿繊維塊の圧縮応力緩和の場合と共通しているものと考え られる [10].

一方，ポリエステル繊維集合体の場合，ポリエステル繊維 自体は一次結合に基づく強固な分子網目構造をもつため, 応 力が加わっても滑りを生じない.このためポリエステル繊維 集合体の応力緩和機構は緩和時間が極めて長く，通常の測定 時間では完全な弾性変形をするものと推定される。したがっ て，異型断面ポリエステルおよび丸断面ポリエステル繊維集 合体における応力緩和挙動は実験式 (3) の形でのみ求めるこ とができた。ポリエステル繊維集合体の応力緩和挙動および その表示式に関する検討は，今後の課題としたい。 


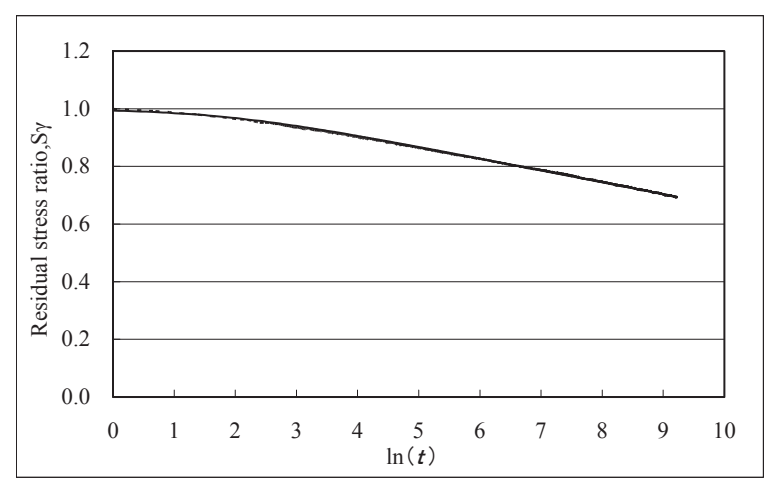

Fig.9 The comparison between experimental value and calculated value by equation(7) based on non-linear two element visco-elastic model for cupra staple fiber assembly.

Sample is compressed from 0.0125 to 0.0139 in volume fraction. Straight line : calculated.

Dotted line : experimental.

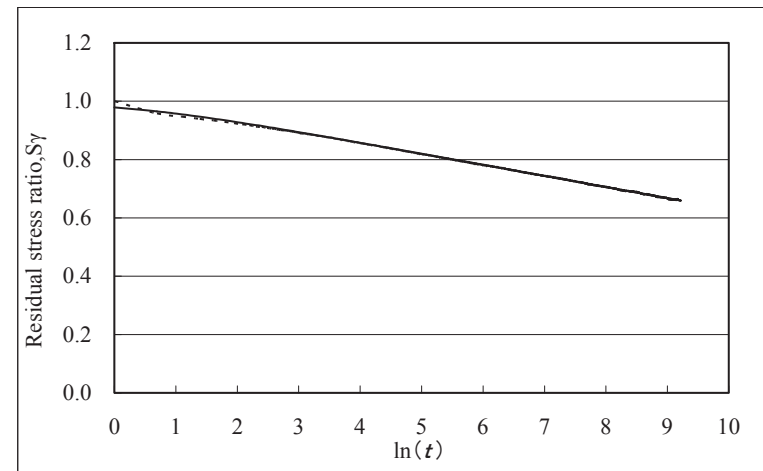

Fig.10 The comparison between experimental value and calculated value by equation(6) based on non-linear two element visco-elastic model for cupra staple fiber assembly.

Sample is compressed from 0.0125 to 0.0156 in volume fraction. Straight line : calculated.

Dotted line : experimental.

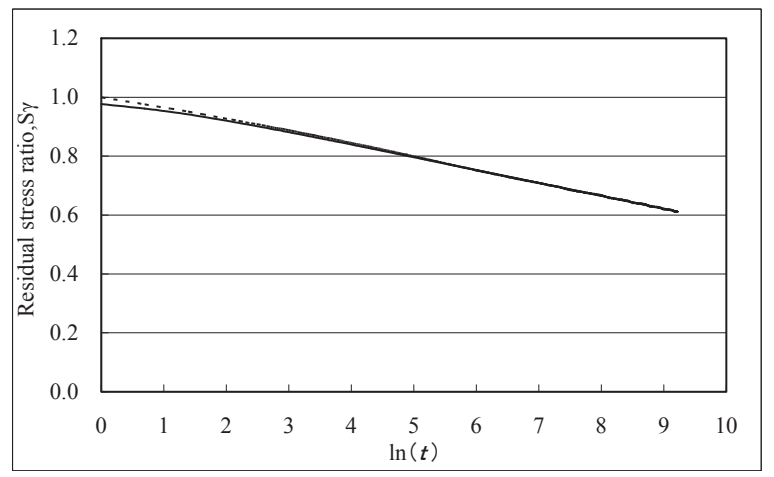

Fig.11 The comparison between experimental value and calculated value by equation(6) based on non-linear two element visco-elastic model for cupra staple fiber assembly.

Sample is compressed from 0.0125 to 0.025 in volume fraction.

Straight line : calculated.

Dotted line : experimental.

\section{4. 結 言}

本研究においては, 異型断面ポリエステル短繊維, 丸断面 ポリエステル短繊維およびキュプラ短繊維の 3 種の円柱状繊 維集合体の圧縮応力緩和特性について実験的に検討し, 以下 の結果を得た。

(1) ある時刻における応力と初期応力の比を応力残留率と定 義すれば，応力残留率曲線は次のような実験式で表すことが できる。

$$
\mathrm{S} \gamma=\sigma / \sigma_{0}=\mathrm{K}\left(\mathrm{a}_{0}-\ln t\right)
$$

ここで $\sigma(\mathrm{Pa})$ は任意時間における応力, $\sigma_{0}(\mathrm{~Pa})$ は初期応力 (時 間 $t=0$ における応力), $t(\mathrm{~s})$ は時間, $\mathrm{K}$ および $\mathrm{a}_{0}$ は試料 種別および測定条件によって決まる定数である.

定数 $\mathrm{K}, \mathrm{a}_{0}$ と変位量の関係から, ポリエステル繊維・キュ プラ繊維集合体の圧縮応力緩和現象が, 非線形粘弾性挙動を 示すことが示唆される.

(2) キュプラ短繊維の緩和速度は他のポリエステル短繊維よ りも明らかに速い。これは $\mathrm{K}$ 值の大小に現れている。 キュ プラの $\mathrm{K}$ 值は異型断面ポリエステルおよび丸断面ポリエス テルの約 2 倍以上である。また，異型断面ポリエステルと丸 断面ポリエステルの $\mathrm{K}$ 值を比べると, 異型断面ポリエステ ルの $\mathrm{K}$ 值の方が丸断面ポリエステルの $\mathrm{K}$ 值に比べて小さい. $\mathrm{K}$ 值が小さいほど圧縮による応力緩和速度が緩やかである. すなわち弾力保持性が高く，へたりにくいといえる．敷きふ とんの寝心地にかかわる実用性能の観点から K 值は重要で ある. K 值の大小を左右する物性としては，けん縮数やけん 縮率，見掛けヤング率などの構造パラメータ，および繊維の 断面形状の違いによる曲げ剛性や繊維間の滑り, 繊維そのも のの粘弾性的性質などが考えられる.

(3) 一定時間における異型断面ポリエステルおよび丸断面ポ リエステルの応力残留率は体積率 0.0179 付近, キュプラの 応力残留率は体積率 0.0208 付近において極小となる。した がって, 纎維集合体の保存という実用的な面で体積の減少を 避けたい場合には，上述の条件を避けなければならない。

(4) キュプラ短纎維集合体の圧縮応力緩和現象は, Eyring 粘 性要素を含む非線形 2 要素モデルによって表示され, 本研究 の測定条件下では以下の厳密式で表される.

$$
\mathrm{S} \gamma=\sigma / \sigma_{0}=\mathrm{K} \ln \left[\operatorname{coth}\left\{1 / 2\left(2 \mathrm{e}^{-\mathrm{a} 0} t+\mathrm{B}\right)\right\}\right]
$$

ここで $\mathrm{S} \gamma$ は応力残留率, $\sigma(\mathrm{Pa})$ は応力, $\sigma_{0}(\mathrm{~Pa})$ は初期応力（時 間 $t=0$ における応力), $t(\mathrm{~s})$ は時間, $\mathrm{K}, \mathrm{a}_{0}$ および $\mathrm{B}$ は試 料種別および測定条件によって決まる定数である.

異型断面ポリエステルおよび丸断面ポリエステル繊維にお いては, キュプラの場合と異なり, 上記実験式に対する厳密 式が成立しなかった。これは，ポリエステル繊維とキュプラ 繊維との分子集合構造の違いによる粘弾性挙動の違いによる ものと考えられる. ポリエステル繊維集合体の応力緩和挙動 およびその表示式に関する検討は今後の課題である。 また, 
本研究で考察した繊維集合体の圧縮応力緩和特性は, 圧縮・ 回復曲線に対して Boltzmann の履歴積分を適用し，そのヒス テリシス機構を解析する際の基礎的知見となる.

\section{謝 辞}

本研究を遂行するにあたり，貴重な試料をご提供して頂き ました旭化成せんい株式会社およびソロテックス株式会社の 関係各位に深謝します。

\section{References}

[1] Nakajima C, Yoneda M, Itoh Y, (2010) J Text Eng, 56, 29-38

[2] Tamura T, Simane U, Takeda S (1989) Sen'i-Gakkaishi, 45, 229-237
[3] Nishide S, Sekiguchi N (1994) Jpn Res Assn Text End-Uses, 35, 480-486

[4] Yokura H, Sukigara S, Niwa M (1995) Jpn Res Assn Text EndUses, 36, 594-601

[5] Yokura H, Sukigara S, Niwa M (1996) Jpn Res Assn Text EndUses, 37, 535-543

[6] Komori T, Itoh M (1991) Text Res J, 61, 420-484

[7] G.A.Carnaby, N.Pan (1989) Text Res J, 59, 275-284

[8] Itoh M, Komori T (1997) Senki Ronbunshu, 50, 165-176

[9] Nogai T, Narumi Y (1972) Senki Ronbunshu , 25, 180-188

[10] Nogai T, Narumi Y, Tanaka K (1974) Senki Ronbunshu, 27, 177-182

[11] Nogai T, Narumi Y, Tanaka K (1975) Senki Ronbunshu, 28, 77-82

[12] Matsuo T, Lei Lu (1996) Proc.25th Text Res Sympo, 70-76

[13] “Sen'i ButsurigaKu”, pp397-403, Sen'i-Gakkai, Maruzen, Tokyo 